\title{
Calcium Hydroxide in Endodontics: An Overview
}

\author{
Raidan Ba-Hattab ${ }^{1 *}$, Manar Al-Jamie1, Haya Aldreib' ${ }^{1}$, Lujain Alessa1, Mohammad Alonazi ${ }^{2}$ \\ ${ }^{1}$ College of Dentistry, Princess Nourah bint Abdulrahman University, Riyadh, Kingdom of Saudi Arabia \\ ${ }^{2}$ Security Forces Clinics, Riyadh, Kingdom of Saudi Arabia \\ Email: ^Rabahattab@pnu.edu.sa, ManarAljamie@hotmail.com, Dr.Alduryb@gmail.com, LujainAlissa@gmail.com, \\ MSAPT_1@hotmail.com
}

How to cite this paper: Ba-Hattab, R., Al-Jamie, M., Aldreib, H., Alessa, L. and Alonazi, M. (2016) Calcium Hydroxide in Endodontics: An Overview. Open Journal o1 Stomatology, 6, 274-289.

http://dx.doi.org/10.4236/ojst.2016.612033

Received: November 21, 2016

Accepted: December 23, 2016

Published: December 26, 2016

Copyright (C) 2016 by authors and Scientific Research Publishing Inc. This work is licensed under the Creative Commons Attribution International License (CC BY 4.0).

http://creativecommons.org/licenses/by/4.0/ (c) (†) Open Access

\begin{abstract}
Background: Calcium hydroxide has been used in dentistry since several decades. It has been used in a number of applications in the field of endodontics such as root resorption, intracanal medicament, and root canal sealers. Although this material exhibits several advantages, it also has some limitations. Objectives: To review the role of calcium hydroxide in the field of endodontics, focusing on its mechanism of action, antimicrobial effects, different applications, cytotoxicity or biocompatibility, and its removal from the root canals. Materials and Methods: An electronic search was done using different databases. Out of 2,664 articles, only 33 articles have been selected to be included in this review because they are directly related to the topic and matched the inclusion criteria of this review: "Language: English" and "Year: 2000-2016". Results: The antimicrobial effect of calcium hydroxide is controversial. Although some studies supported the effectiveness of calcium hydroxide against some bacteria others reported its limitation against fungal infection. Calcium hydroxide can be used effectively as intracanal medicament, root canal sealer, in weeping canals, for perforation management and root resorption. Conclusions: Despite the limitation of antimicrobial activity of calcium hydroxide, it is used effectively in a number of treatment modalities in endodontics. Due to its biological and therapeutical properties, calcium hydroxide is the material of choice for all pulp therapy. However, when using calcium hydroxide as a dressing material in root canal treatment caution should be taken to prevent the overextension of the paste beyond the tooth apex and avoid the harmful side effects.
\end{abstract}

\section{Keywords}

Calcium Hydroxide, Endodontics, Root Canal Treatment, Applications in Endodontics, Mechanism of Action, Cytotoxicity, Biocompatibility, Removal of Calcium Hydroxide from the Canals 


\section{Introduction}

Calcium hydroxide has been used by dentists in the clinical practice for over a century [1]. In 1920, Herman introduced calcium hydroxide to dentistry as a pulp-capping material but today it is used widely in the field of endodontics [2] [3].

Calcium hydroxide is a white odourless powder with the chemical formula $\mathrm{Ca}(\mathrm{OH})_{2}$ and a molecular weight of 7.08. Chemically, it is classified as a strong base in contact with aqueous fluids (its $\mathrm{pH}$ is about 12.5 - 12.8), and dissociate into calcium and hydroxyl ions [4]. Calcium hydroxide is used and supplied in various forms. It is used like a varnish when supplied as a liquid containing calcium hydroxide suspended in a solvent or when supplied as a paste in which calcium hydroxide is suspended in methylcellulose. Another form of calcium hydroxide is marketed as a base and a catalyst. By using the catalyst, calcium hydroxide reacts faster and forms a hard, amorphous compound within matter of minute in the oral environment. Finally, calcium hydroxide supplied as a paste contains a polymer resin that can be hardened when exposed to illumination from a handheld blue light source [2].

Nowadays, calcium hydroxide is widely used in the field of endodontics due to its advantages such as:

- Initially bactericidal effect then bacteriostatic.

- Promotes healing and repair.

- High pH stimulates fibroblasts.

- Stops internal resorption.

- Neutralizes low pH of acids.

- Inexpensive and easy to use [5].

On the other hand, calcium hydroxide has some disadvantages such as:

- Does not exclusively stimulate dentinogenesis.

- Does exclusively stimulate reparative dentin.

- Associated with primary tooth resorption.

- May dissolve after one year with cavosurface dissolution.

- Degrades upon tooth flexure.

- Marginal failure with amalgam condensation.

- Does not adhere to dentin or resin restoration [5].

The purpose of this literature review is to focus on the role of calcium hydroxide in the field of endodontics including a brief explanation of its mechanism of action, antimicrobial effects, different applications, cytotoxicity or biocompatibility, and finally removal of calcium hydroxide from the root canals.

\section{Materials and Methods}

An electronic search was done using the following databases: PubMed, Cochrane and Google Scholar. The online searching was conducted following these keywords: "Calcium hydroxide"; "endodontics"; "root canal treatment"; "applications in endodontics"; "mechanism of action"; "cytotoxicity"; "biocompatibility"; "removal of calcium hydroxide from the canals". Out of 2664 articles, only 33 articles have been selected to be in- 
cluded in this review because they are directly related to the topic and also these articles have been chosen based on the inclusion criteria: "Language: English" and "Year: 20002016". A table was constructed to express the details of the searched articles in the appendix part of this paper (Table A1) and the articles screening process explained in the flow Diagram 1.

\section{Antimicrobial Effect of Calcium Hydroxide}

Endodontic infections occur as a result of microbial mixtures containing bacteria represented by Enterococcus faecalis [6] and fungi which are especially represented by Candida Albicans [7]. Anaerobic bacteria with their endotoxins on their cell walls also predominant in this microbial diversity and can be detected especially gram negative [8]. It is well established that the complete removal of bacteria from the root canal system is difficult even with the new endodontic techniques. Combining procedures to eliminate bacterial infection may be accepted. These including mechanical root canal debridement by proper shaping, irrigation by chemical agents such as sodium hypochlorite $(\mathrm{NaOCl})$ or hydrogen peroxide $\left(\mathrm{H}_{2} \mathrm{O}_{2}\right)$ in addition to the intracanal medicament containing antimicrobial agents such as calcium hydroxide [9] [10].

\subsection{Mechanism of Action}

The release of hydroxyl ions in an aqueous environment is essential for the activation of calcium hydroxide against microbes. These ions reacted intensively with several biomolecules due to their highly oxidant free radicals. As this reactivity is unspecified, the free radicals most likely gathered at the sites of generation. Hydroxyl ions have fatal effects on bacterial cells. They may damage the cytoplasmic membrane of bacteria, denature their proteins, or damage the DNA. It is difficult to prove which of these three

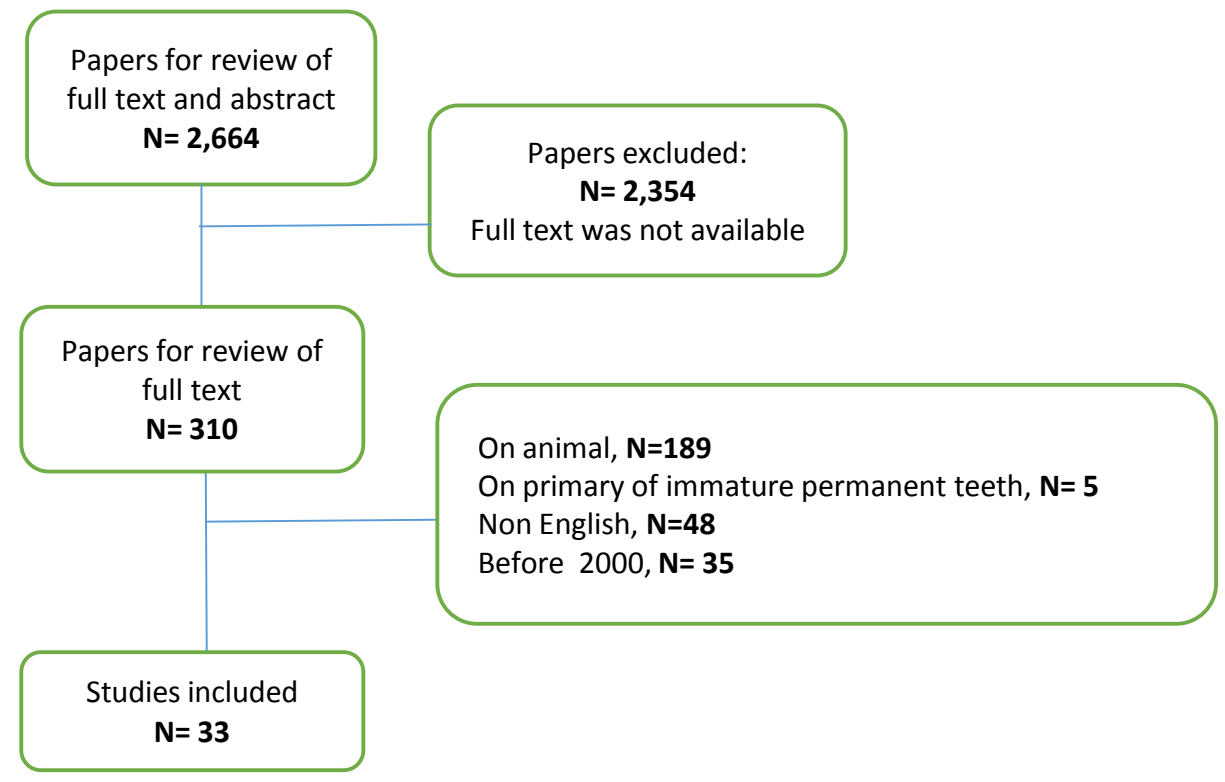

Diagram 1. Article screening process. 
mechanisms is mainly involved in the death of bacterial cells after their exposure to a strong base. Since enzymatic sites are located in the cytoplasmic membrane of bacteria, hydroxyl ions from calcium hydroxide exert their mechanism of action there. Extracellular enzymes favor digestion, and through hydrolysis act on nutrients, carbohydrates, proteins, and lipids, whereas intracellular enzymes act on the respiratory activity of the cellular wall structure.

The high concentration of hydroxyl ions from calcium hydroxide alters the $\mathrm{pH}$ gradient of the cytoplasmic membrane damaging its protein. The integrity of the cytoplasmic membrane is altered by the high alkalinity of calcium hydroxide by acting on the organic components and transporting the nutrients or by a saponification reaction in which the phospholipids or unsaturated fatty acids of the cytoplasmic membrane are destructed during the peroxidation process [11].

\subsection{Antibacterial Effect}

The antibacterial activity of calcium hydroxide is a major concern to most of the scientists. Cook et al. evaluated the quality of root canal filling with or without calcium hydroxide application prior to the root canal filling or $2 \%$ chlorhexidine on the persistence of bacterial infection on the dentinal tubules, they found that the use of $2 \%$ chlorhexidine followed by root canal filling was more effective in removing the bacterial infection especially $E$. faecalis than placement of calcium hydroxide or immediate canal filling [12]. Peters et al. claimed that the number of positive gram bacteria increased in root canal system after dressing with calcium hydroxide [13]. Other studies showed that calcium hydroxide could not reliably remove bacteria from the root canal system or change the culture from gram-negative to gram-positive [14]. It has been reported that the 7 days application of calcium hydroxide is effective in bacterial elimination while the 10 minutes application was not effective [11].

\subsection{Antifungal Effect}

The presence of Fungi represented by $C$. albicans was detected in primary root canal infection but is more common in failed endodontic treatments. Their occurrence varies between $1 \%$ and $17 \%$.

It was reported that $C$. albicans cells are more resistant to calcium hydroxide than did $E$. faecalis. Since $C$. albicans survives at a wide range of $\mathrm{pH}$ values, high $\mathrm{pH}$ of calcium hydroxide may not have any effect on $C$. albicans. Additionally, calcium hydroxide pastes provide $\mathrm{Ca}^{2+}$ ions that are essential for the growth of $C$. albicans which explained the limited or no effect of calcium hydroxide to fungal infection [11].

\section{Applications of Calcium Hydroxide in Endodontics}

\subsection{Intracanal Medicaments}

Endodontic treatment requires the use of suitable intracanal medicaments that simultaneously eliminate bacteria, prevent their growth, stop their ingress and cut off their nutrient supply [15]. Calcium hydroxide is most commonly used as an intracanal me- 
dicament for disinfection of the root canal system [2]. As mentioned above, the application of calcium hydroxide paste at intervals of at least 7 days is able to eliminate and/or reduce the total number of bacteria surviving even after biomechanical preparation [11]. It has a wide range of antimicrobial activity against bacteria, but has limited effect against E. faecalis and C. albicans. It is also an effective anti-endotoxin agent [2]. Calcium hydroxide has a little or no effect on the intensity or severity of postoperative pain following endodontic treatment. In contrast, application of corticosteroid paste in the canal reduces the postoperative pain [16]. The Effect of calcium hydroxide on pro-Inflammatory cytokines was studied and concluded that it leads to denaturation of these pro-inflammatory mediators such as interleukin-1 $\alpha$ (IL-1 $\alpha$ ), tumor necrosis factor $\alpha(\mathrm{TNF} \alpha)$ and calcitonin gene-related peptide (CGRP) that is a potential mechanism by which calcium hydroxide contributes to the resolution of periradicular periodontitis [17]. Different techniques can be used for the placement of calcium hydroxide in the canals. Tan et al. compared the use of syringe and \#25 finger spreader (group 1), syringe and \#4 rotary lentulo spiral (group 2), specially designed paste carrier (group 3 ), they found that, the specially designed paste carrier was more effective than other tested techniques in the intracanal placement of calcium hydroxide [18].

\subsection{Root Canal Sealer}

The main objective of root canal obturation is to achieve a tight seal of the root canal system which in turn enhance the healing process of periapical and apical regions after endodontic therapy [19].

It is well clear that some forms of cement are required when filling the root canals to fill the minor spaces between the core material and the dentinal walls of the canal to prevent leakage. The outcome of endodontic treatment may influenced by sealer selection [2]. The properties of an ideal root canal sealer were outlined by Grossman (Table 1) [20]. The dissociation of calcium hydroxide into $\mathrm{Ca}^{++}$and $\mathrm{OH}^{-}$is necessary for its therapeutic effect. Therefore, dissolving an endodontic sealer based on calcium hydroxide resulted in the loss of its solid content and consequently obturation voids are formed [2]. The antibacterial activity of some calcium hydroxide based sealers such as RealSeal, Sealapex, Apexit, and Apexit Plus is related to the release of hydroxyl ions. These sealers may also help in the formation of root-end hard tissue. Despite their advantages, calcium hydroxide-based sealers exhibit some disadvantages such as limited antibacterial activity, poor cohesive strength, greater solubility, and marginal leakage [1] [21].

\subsection{In Weeping Canal}

Weeping canal is a canal from which constant clear or reddish exudation is appeared. This exudate is associated with a large apical radiolucency. The tooth is difficult to treat as when opened, exudate stops but it again reappears in next appointment. Signs and symptoms are varies from symptomless to tenderness to percussion and palpation. Obturation of canals with exudates is contraindicated. 
Table 1. Requirements and characteristics for root canal sealer-Grossman (1982).

1) It should be tacky when mixed to provide good adhesion between it and the canal wall when set.

2) It should make a hermetic seal.

3) It should be radiopaque so that it can be visualized on the radiograph.

4) The particles of powder should be very fine so that they can mix easily with liquid.

5) It should not shrink upon setting.

6) It should not discolour tooth structure.

7) It should be bacteriostatic or at least not encourage bacterial growth.

8) It should set slowly.

9) It should be insoluble in tissue fluids.

10) It should be well tolerated by the periapical tissue.

11) It should be soluble in common solvents if it is necessary to remove the root canal filling [20].

For such teeth, application of calcium hydroxide in the canal after drying with sterile absorbent paper points is helpful. This is because of its high alkalinity, which changes the acidic $\mathrm{pH}$ of periapical tissues to a more basic environment [2] [5]. Two other mechanisms have also been proposed: 1) build up bone in the lesion due to the calcifying potential of calcium hydroxide and 2) the residual chronically inflamed tissue is cauterized by the caustic action of calcium hydroxide [4].

\subsection{Perforation Management}

One of procedural errors that can happen during root canal treatment is root or furcation perforation. This error can cause failure of the treatment and subsequent tooth loss. Calcium hydroxide was one of the most preferred materials that have been used to seal and manage perforations. It has many advantages in this treatment modality such as stimulation of hard tissue formation, easy preparation, rapid resorption when extruded into the periodontium and healing enhancement of damaged periodontal tissues [4]. In case of crestal and furcation perforations, calcium hydroxide is not the suitable material for the seal as a pocket is formed due initial inflammatory response to these materials and subsequent breakdown of the supporting tissues. Although calcium hydroxide possesses disadvantages-as mentioned previously, calcium hydroxide has been recommended as a traditional agent to manage perforations, and its usage still indicated to control infection, stop bleeding and as a temporary solution when inadequate time is available to perform a permanent repair. However, mineral trioxide aggregate (MTA) now is the material of choice for the permanent repair of perforations from both a conventional and surgical approach [4] [21].

\subsection{Role in Root Resorption}

Root resorption can be classified into internal, external or root-ended resorption based on the site of origin, and can affect the cementum and/or dentine of the root. Since cal- 
cium hydroxide has alkaline $\mathrm{pH}$, it actively influences the local environment around a resorptive area by reducing osteoclast activity and stimulating repair. The alkaline calcium hydroxide neutralizes the acidic environment which exists in the region of resorption, reversing the reaction and thus stimulating hard tissue formation. The diffusion of hydroxyl ions released by calcium hydroxide through the dentinal tubules that directly communicate with periodontal space would increase the $\mathrm{pH}$ of periodontal space from 6.0 to 7.4 - 9.6 [21]. To treat an internal resorption, the canal and resorption lacuna are filled with calcium hydroxide paste. In this way calcium hydroxide will induce the necrotization process of the remaining tissue in the lacuna, and then by irrigation with sodium hypochlorite the necrotic residuals are removed [4]. In case of lateral resorption, pulp extirpation, debridement of root canal and application of calcium hydroxide are the preferred therapy. The resorptive defect should be filled with calcium hydroxide at 3-month intervals until it reveals hard tissue formation, confirmed by both direct examination through the access cavity and radiograph [4] [11]. After establishment of physical barrier, the defect can be compacted with Gutta-percha [3]. Recently, MTA is an alternative for calcium hydroxide in the management of internal root resorption. It has been reported that MTA used successfully in surgical and non-surgical treatment of internal resorption [4].

\section{Cytotoxicity and Biocompatibility of Calcium Hydroxide}

The primary function of the pulp is dentin formation which started when the peripheral mesenchymal cells differentiated into odontoblasts and the collagen matrix begins to deposit, in a sequence of deposition/mineralization that will lead to complete tooth formation. Dentin is produced by the pulp continuously due to the tooth aging, even after the initial formation. Physical and/or chemical injuries may also produce reparative dentin [22]. Dentin-pulp complex can be protected by applying one or more layers of some specific materials between the restorative material and dental tissues. Protection of the dentin-pulp complex leads also to pulp vitality recovery. Calcium hydroxide based products are the materials that can be used for this purpose [23]. Cytotoxicity and biocompatibility of these materials have been widely studied in different cell cultures [22].

\subsection{Effect of Calcium Hydroxide on Pulp Vitality}

Pulp tissue is affected by environmental impacts such as heat, mechanical trauma as well as microbial toxins. After multiple injuries, the pulp cells have the capacity to repair and differentiate into odontoblasts and produce dentin matrix proteins during wound healing process. Therefore, not all the inflammatory reaction leads to permanent damage [22]. Due to its direct and indirect effect in pulp repair, calcium hydroxide considers as the most important dental material which is used as the gold standard in biocompatibility tests. Since calcium hydroxide is biologically and therapeutically potential, it is the material of choice for all pulp conservation treatment [23]. Many studies reported that pulp repair and formation of hard tissue barrier can be induced when 
the pulp tissue directly capped with the different form of calcium hydroxide (Figure 1 and Figure 2) [22]. Clinically, the formation of hard tissue barrier after pulp capping is precious as it provides natural protection from bacterial ingress and chemical products [22]. The mechanism of using calcium hydroxide as pulp capping agent is unclear. However, it has been reported that some proteins and growth factors are released from dentine because of the dissolved high alkaline $\mathrm{pH}$ of calcium hydroxide solution. These mechanisms may stimulate pulp repair and formation of hard tissue barrier. Additionally, a layer of coagulation necrosis is induced when the high $\mathrm{pH}$ of calcium hydroxide in direct contact with pulp tissue [22].

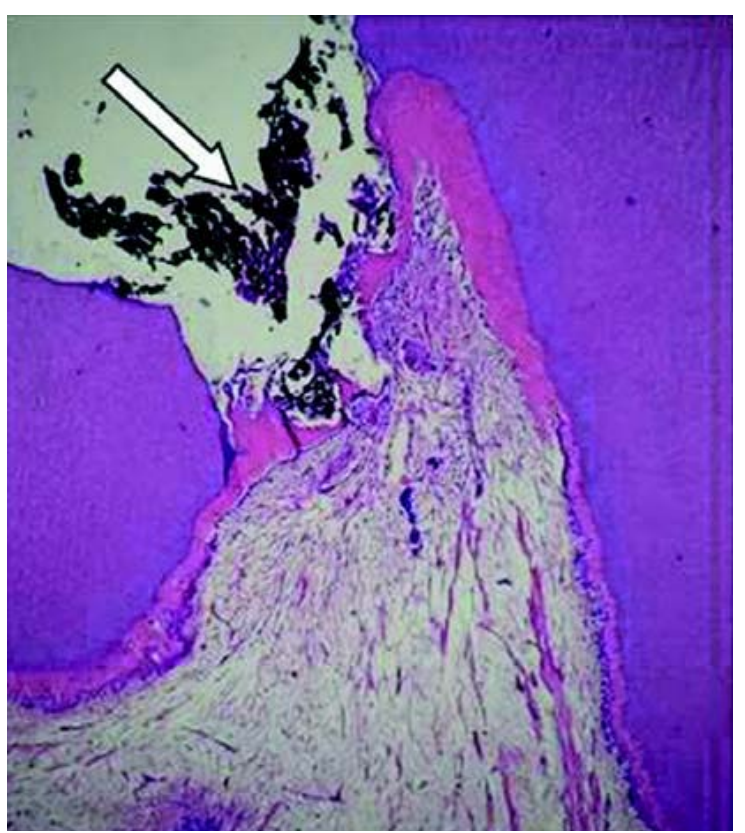

Figure 1. Pulp exposure capped with calcium hydroxide, (arrow). Observe that 30 days after the pulp, therapy, a partial hard tissue barrier was formed, adjacent to the capping agent. HE, $\times 32[22]$.

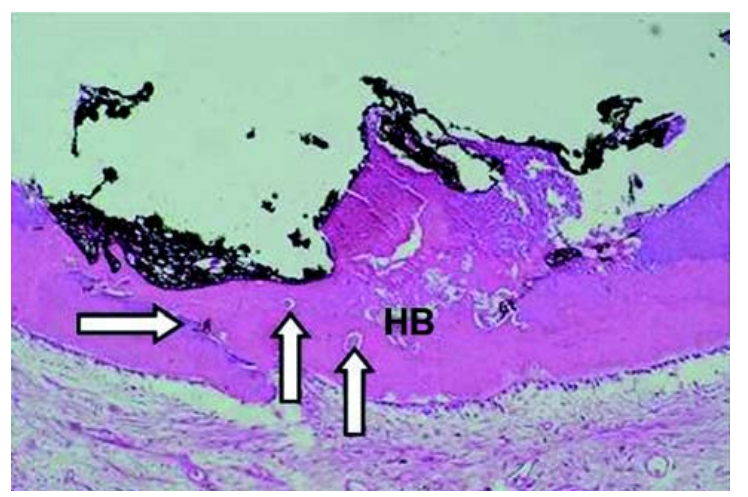

Figure 2. Sixty days after applying calcium hydroxide, on the pulp tissue, a complete hard tissue barrier, (HB) is formed. HE. $\times 125$ [22]. 


\subsection{Effect of Calcium Hydroxide on Periapical Area}

When using calcium hydroxide past in root canal treatment as intracanal medicament, it might be accidentally extruded through the root apex. In case of large chronic periapical lesions, intentional pressing of calcium hydroxide beyond the root canal and into the periradicular tissue has been supported by some researchers. They claimed that calcium hydroxide enhances the healing and osseous repair by direct effect on inflamed tissues. However, this hypothesis was rejected by other researchers and not widely used as extrusion of calcium hydroxide beyond the apex can lead to damaging effects [24].

In Endodontics, barium sulfate $\left(\mathrm{BaSO}_{4}\right)$ is added to calcium hydroxide paste as a radiopaque agent. Extrusion of calcium hydroxide paste containing barium sulfate beyond root canal can obscure the apex, and is not easily resorbed over time (Figure 3 and Figure 4) [21], also barium sulfate enhances the release of inflammatory mediators responding to polymethylmethacrylate (PMMA) particles. Therefore, the healing process might be delayed when using calcium hydroxide paste including barium sulfate, or in this condition the radiographic interpretation of osseous healing might be difficult. Furthermore, the effect of extruded calcium hydroxide paste including a barium sulfate and/or another radiopaque agent and the healing of periapical lesions is not completely clear. Consequently, pure calcium hydroxide is preferred by most clinicians as they believe that the commercial ingredients may delay the healing process they want [24] [25].

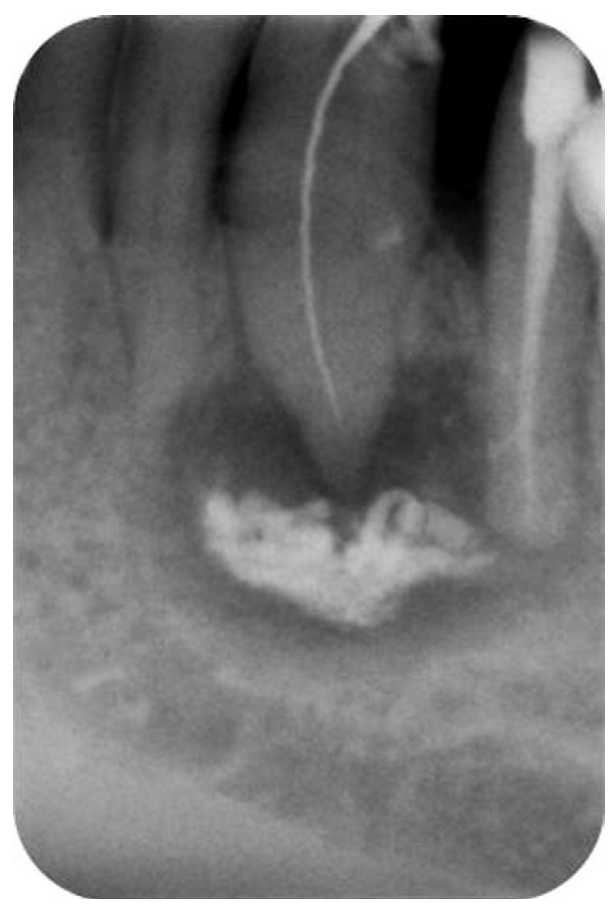

Figure 3. Radiograph after placement of an intracanal, calcium hydroxide paste dressing with, unintentional periapical overextension [24] [25]. 


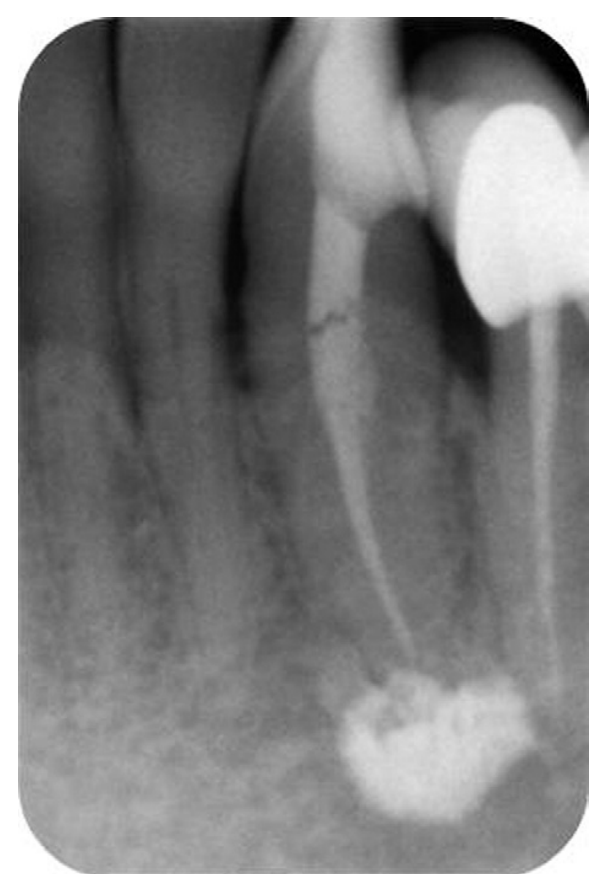

Figure 4. The 36-month control radiograph showing healing of, the apical lesion and the presence of a white radiopaque, spot at the place where calcium hydroxide remnants, were originally present [24] [25].

\section{Removal of Calcium Hydroxide from the Canals}

Calcium hydroxide is the most commonly used intracanal medicament [26]. However, incomplete removal of the material from the canal may adversely affect sealer performance and subsequent long-term prognosis [27] [28]. Thorough cleaning of root canal system can be achieved by delivering effective irrigation, solution activation as well as direct contact with all canal walls especially in the apical third. Several methods have been described to remove calcium hydroxide from the canal. The most commonly used method is using a master apical file to the working length in conjunction with EDTA and sodium hypochlorite [29]. Using rotary files, sonic and ultra-sonic activated tips with irrigation have also been recommended. However, all of the mentioned methods are not able to remove calcium hydroxide from the canals especially in the apical third [30] [31] [32]. It has been reported that continuous irrigations with vibrating motion may have positive effects on cleaning process, particularly in the apical third of the canal which is the most difficult part to clean [33].

\section{Conclusion}

Calcium hydroxide has been used for different purpose in endodontics and available in different forms. Despite its wide range of antimicrobial activity, calcium hydroxide is less effective against some species. Its cytotoxicity appears to be milder than other groups of sealers. The biocompatibility of calcium hydroxide based sealers is controver- 
sial and because of their solubility, they do not fulfill all the criteria of an ideal sealer. It is difficult to remove calcium hydroxide completely from the root canals. Further studies are recommended to evaluate the effectiveness of calcium hydroxide and its applications in the field of endodontics.

\section{References}

[1] Desai, S. and Chandler, N. (2009) Calcium Hydroxide-Based Root Canal Sealers: A Review. Job Openings for Economists, 35, 475-480. https://doi.org/10.1016/j.joen.2008.11.026

[2] Mustafa, M., Saujanya, K.P., Jain, D., Sajjanshetty, S., Arun, A., Uppin, L. and Kadri, M. (2012) Role of Calcium Hydroxide in Endodontics: A Review. Global Journal of Medicine and Public Health, 1, 66-70.

[3] Fuks, A.B. (2008) Vital Pulp Therapy with New Materials for Primary Teeth: New Directions and Treatment Perspectives. Job Openings for Economists, 34, 18-24. https://doi.org/10.1016/j.joen.2008.02.031

[4] Mohammadi, Z. and Dummer, P.M.H. (2011) Properties and Applications of Calcium Hydroxide in Endodontics and Dental Traumatology. L'institut d'Etudes Judiciaires, 44, 697730. https://doi.org/10.1111/j.1365-2591.2011.01886.x

[5] Agrawal, V. (2011) Calcium Hydroxide: A Miracle Munition. Indian Journal of Dental Research and Review, Content-April-September 2011, 16-18.

[6] Gomes, B.P., Pinheiro, E.T., Jacinto, R.C., Zaia, A.A., Ferraz, C.C.R. and Souza-Filho, F.J. (2008) Microbial Analysis of Canals of Root-Filled Teeth with Periapical Lesions Using Polymerase Chain Reaction. Job Openings for Economists, 34, 537-540. https://doi.org/10.1016/j.joen.2008.01.016

[7] Hancock, H., Sigurdsson, A., Trope, M. and Moiseiwitsch, J. (2001) Bacteria Isolated after Unsuccessful Endodontic Treatment in a North American Population. Oral Surgery, Oral Medicine, Oral Pathology, Oral Radiology, and Endodontology, 91, 579-586.

[8] Leonardo, M., Silva, R., Assed, S. and Nelson-Filho, P. (2004) Importance of Bacterial Endotoxin (LPS) in Endodontics. Journal of the American Oriental Society, 12, 93-98.

[9] Garcez, S., Nuñez, S., Hamblin, M. and Ribeiro, M. (2007) Antimicrobial Effects of Photodynamic Therapy on Patients with Necrotic Pulps and Periapical Lesion. Job Openings for Economists, 34, 138-142.

[10] Bonsor, S.J., Nichol, R., Reid, T.M.S. and Pearson, G.J. (2006) Microbiological Evaluation of Photo-Activated Disinfection in Endodontics (an in Vivo Study). British Dental Journal, 200, 337-341. https://doi.org/10.1038/sj.bdj.4813371

[11] Mohammadi, Z., Shalavi, S. and Yazdizadeh, M. (2012) Antimicrobial Activity of Calcium Hydroxide in Endodontics: A Review. Chonnam Medical Journal, 48, 133-140.

https://doi.org/10.4068/cmj.2012.48.3.133

[12] Cook, J., Nandakumar, R. and Fouad, A.F. (2007) Molecular- and Culture-Based Comparison of the Effects of Antimicrobial Agents on Bacterial Survival in Infected Dentinal Tubules. Journal of Endodontics, 33, 690-702. https://doi.org/10.1016/j.joen.2007.01.022

[13] Peters, L.B. and Wesselink, P. R. (2002) Periapical Healing of Endodontically Treated Teeth Inone and Two Visits Obturated in the Presence or Absence of Detectable Microorganisms. International Endodontic Journal, 35, 660-667. https://doi.org/10.1046/j.1365-2591.2002.00541.x

[14] Sathorn, C., Parashos, P. and Messer, H. (2006) Antibacterial Efficacy of Calcium Hydroxide Intracanal Dressing: A Systematic Review and Meta-Analysis. International Endodontic 
Journal, 40, 2-10. https://doi.org/10.1111/j.1365-2591.2006.01197.x

[15] Siqueira, J.F., Rôças, I.N., Magalhães, F.A. and Uzeda, M. (2001) Antifungal Effects of Endodontic Medicaments. Australian Endodontic Journal, 27, 112-114. https://doi.org/10.1111/j.1747-4477.2001.tb00471.x

[16] Anjaneyulu, K. and Nivedhitha, M.S. (2014) Influence of Calcium Hydroxide on the Post-Treatment Pain in Endodontics: A Systematic Review. Journal of Conservative Dentistry, 17, 200-207. https://doi.org/10.4103/0972-0707.131775

[17] Khan, A.A., Sun, X. and Hargreaves, K.M. (2008) The Effect of Calcium Hydroxide on Pro-Inflammatory Cytokines and Neuropeptides. Journal of Endodontics, 34, 1360-1363. https://doi.org/10.1016/j.joen.2008.08.020

[18] Tan, J.M.E., Parolia, A. and Pau, A.K.P. (2013) Intracanal Placement of Calcium Hydroxide: A Comparison of Specially Designed Paste Carrier Technique with Other Techniques. BMC Oral Health, 13, 52. https://doi.org/10.1186/1472-6831-13-52

[19] Holland, R., Murata, S.S., Silva, M.N., Dezan, J.E., Souza, V. and Bernabé, P.F.T. (2004) Influence of the Sealer and a Plug in Coronal Leakage after Post Space Preparation. Journal of Applied Oral Science, 12, 223-226. https://doi.org/10.1590/S1678-77572004000300012

[20] Grossman, L. (1982) Obturation of Root Canal. In: Grossman, L., Ed., Endodontic Practice, 10th Edition, Lea and Febiger, Philadelphia, 343.

[21] Revathi, N. and Sharath Chandra, S.M. (2014) Merits and Demerits of Calcium Hydroxide as a Therapeutic Agent: A Review. International Journal of Dental Sciences and Research, 2, 1-4. https://doi.org/10.12691/ijdsr-2-6B-1

[22] Modena, K.C.S., Casas-Apayco, L.C., Atta, M.T., Costa, C.A.S., Hebling, J., Sipert, C.R., Navarro, M.F. and Santos, C.F. (2009) Cytotoxicity and Biocompatibility of Direct and Indirect Pulp Capping Materials. Journal of Applied Oral Science, 17, 544-554. https://doi.org/10.1590/S1678-77572009000600002

[23] Briso, A., Rahal, V., Mestrener, S.R. and Dezan, J.E. (2006) Biological Response of Pulps Submitted to Different Capping Materials. Brazilian Oral Research, 20, 219-225.

https://doi.org/10.1590/S1806-83242006000300007

[24] Orucoglu, H. and Cobankara, F. (2008) Effect of Unintentionally Extruded Calcium Hydroxide Paste Including Barium Sulfate as a Radiopaquing Agent in Treatment of Teeth with Periapical Lesions: Report of a Case. Journal of Endodontics, 34, 888-891.

https://doi.org/10.1016/j.joen.2008.04.012

[25] Sharma, S., Webb, R., Macpherson, D. and Wilson, A. (2008) Severe Tissue Necrosis Following Intra-Arterial Injection of Endodontic Calcium Hydroxide: A Case Series. Oral Surgery, Oral Medicine, Oral Pathology, Oral Radiology, and Endodontology, 105, 666-669. https://doi.org/10.1016/j.tripleo.2007.11.026

[26] Victorino, F., Bramante, C., Zapata, R.O., Casaroto, A.R., Garcia, R.B., Moraes, I.G. and Hidalgo, M.M. (2010) Removal Efficiency of Propolis Paste Dressing from the Root Canal. Journal of Applied Oral Science, 18, 621-624. https://doi.org/10.1590/S1678-77572010000600014

[27] Barbizam, J., Trope, M., Teixeira, EC., Tanomaru-Filho, M. and Teixeira, F. (2008) Effect of Calcium Hydroxide Intracanal Dressing on the Bond Strength of a Resin-Based Endodontic Sealer. Brazilian Dental Journal, 19, 224-227. https://doi.org/10.1590/S0103-64402008000300009

[28] Faria, G., Kuga, M., Ruy, A., Aranda-Garcia, A., Bonettifilho, I., Guerreiro-Tanomaru, J. and Leonardo, R.T. (2013) The Efficacy of the Self-Adjusting File and ProTaper for Removal of Calcium Hydroxide from Root Canals. Journal of Applied Oral Science, 21, 346-350. 
https://doi.org/10.1590/1678-775720130034

[29] Balvedi, R., Versiani, M., Manna, F. and Biffi, J. (2010) A Comparasion of Two Techniques for the Removal of Calcium Hydroxide from Root Canals. International Endodontic Journal, 43, 763-768. https://doi.org/10.1111/j.1365-2591.2010.01718.x

[30] Kuga, M.C., Tanomaru-Filho, M., Faria, G., Só, M.V.R., Galletti, T. and Bavello, J.R.S. (2010) Calcium Hydroxide Intracanal Dressing Removal with Different Rotary Instruments and Irrigating Solutions: A Scanning Electron Microscopy Study. Brazilian Dental Journal, 21, 310-314. https://doi.org/10.1590/S0103-64402010000400004

[31] Rodig, T., Vogel, S., Zapf, A. and Hülsmann, M. (2010) Efficacy of Different Irrigants in the Removal of Calcium Hydroxide from Root Canals. International Endodontic Journal, 43, 519-527. https://doi.org/10.1111/j.1365-2591.2010.01709.x

[32] Tasdemir, T., Celik, D., Er, K., Yildirim, T., Ceyhanli, K.T. and Yeşilyurt, C. (2011) Efficacy of Several Techniques for the Removal of Calcium Hydroxide Medicament from Root Canals. International Endodontic Journal, 44, 505-509.

https://doi.org/10.1111/j.1365-2591.2011.01854.x

[33] Gu, L.S., Kim, J.R., Ling, J., Choi, K.K., Pashley, D.H. and Tay, F.R. (2009) Review of Contemporary Irrigant Agitation Techniques and Devices. Journal of Endodontics, 35, 791-804. https://doi.org/10.1016/j.joen.2009.03.010 


\section{Appendix}

Table A1. Details of the searched articles (narrative review).

\begin{tabular}{|c|c|c|c|c|}
\hline No. & Author/Year & Language & Type of study & Results/Outcomes \\
\hline 1 & $\begin{array}{l}\text { Desai, S., Chandler, N. } \\
\qquad(2009)\end{array}$ & English & Review of article & $\begin{array}{l}\text { Calcium hydroxide-based root canal sealers do not fulfil all the criteria of ideal } \\
\text { root canal sealer. Comparative studies reveal their mild cytotoxicity, but their } \\
\text { antibacterial effects are variable. }\end{array}$ \\
\hline 2 & $\begin{array}{l}\text { Mustafa, M., Saujanya, } \\
\text { K.P., Jain, D., } \\
\text { Sajjanshetty, S., Arun, } \\
\text { A., Uppin, L., Kadri, } \\
\quad \text { M. (2012) }\end{array}$ & English & Review of article & $\begin{array}{l}\text { Calcium hydroxide is used widely in the field of endodontics. It is used and } \\
\text { supplied in various forms. Its alkalinity changes the acidic } \mathrm{pH} \text { of periapical } \\
\text { tissues of a weeping canal to a more basic environment in }\end{array}$ \\
\hline 3 & Fuks, A.B. (2008) & English & Review of article & $\begin{array}{l}\text { Mineral trioxide aggregate and ferric sulfate can be used appropriately as } \\
\text { alternatives to formocresol for pulpotomies in primary teeth with exposed pulps. } \\
\text { A high-speed handpiece or laser might result in an exposure of a "normal" pulp } \\
\text { that would otherwise not be exposed. }\end{array}$ \\
\hline 5 & Agrawal, V. (2011) & English & Review of article & $\begin{array}{l}\text { Calcium hydroxide has high alkalinity property. it has a mild irritation on the } \\
\text { pulp. Its dissociation into hydroxyl ions and calcium is necessary for its } \\
\text { antimicrobial activity. It is supplied in several forms. It is available in powder } \\
\text { form, as a liquid containing calcium hydroxide suspended in a solvent, as a } \\
\text { single paste, as two-paste: catalyst and base system and a calcium as a paste that } \\
\text { contains a polymer resin. }\end{array}$ \\
\hline 8 & $\begin{array}{l}\text { Leonardo, M., Silva, R., } \\
\text { Assed, S., Nel- } \\
\text { son-Filho, P. (2004) }\end{array}$ & English & Review of article & $\begin{array}{l}\text { All teeth with pulp necrosis and radiographically visible chronic periapical lesion } \\
\text { have bacterial endotoxin (LPS), which is a component of Gram-negative cell } \\
\text { wall. It plays the main role in the genesis and persisting of periapical lesions } \\
\text { because of inflammation induction as well as bone resorption. In vitro and in } \\
\text { vivo, Calcium hydroxide inactivates bacterial endotoxin. }\end{array}$ \\
\hline 9 & $\begin{array}{l}\text { Garcez, S., Nuñez, S., } \\
\text { Hamblin, M., Ribeiro, } \\
\text { M. (2007) }\end{array}$ & English & An in vivo study & $\begin{array}{l}\text { Adding Photodynamic therapy to endodontic treatment enhances the reduction } \\
\text { of bacterial load and may be a suitable approach for the treatment of oral } \\
\text { infections. }\end{array}$ \\
\hline 10 & $\begin{array}{l}\text { Bonsor, S.J., Nichol, R., } \\
\text { Reid, T.M.S., Pearson, } \\
\text { G.J. (2006) }\end{array}$ & English & $\begin{array}{l}\text { An in vivo study } \\
\text { (A randomised } \\
\text { trial) }\end{array}$ & $\begin{array}{l}\text { After using conventional irrigants in root canal treatment, the "Photodynamic } \\
\text { Therapy" system offers a means of destroying the remaining bacteria. }\end{array}$ \\
\hline
\end{tabular}




\section{Continued}

Mohammadi, Z.,

11 Shalavi, S., Yazdizadeh M. (2012)

12

Cook, J., Nandakumar, R., Fouad, A.F. (2007)

13

Peters, L.B., Wesselink, P.R. (2002)

Sathorn, C., Parashos, P., Messer, H. (2006)

Siqueira, J.F. Jr., Rôças,

Anjaneyulu, K, Nivedhitha, M (2014)

Khan, A, Sun, X, Hargreaves, M (2008)

Tan, J., Parolia, A., Pau, A. (2013)

Grossman, L., 10th ed. Chapter 15 (1982)

Revathi, N., Sharath Chandra, S.M.

Modena, K.C.S., Casas-Apayco, L.C.,

Atta, M.T., Costa,

C.A.S., Hebling, J., et al. (2009)

Briso, A.L.F., Rahal, V., 23 Mestrener, S.R., Dezan, J.E. (2006)
English

Review of article

English An in vitro study

English An in vivo study

Review of article

(systematic

review and

meta-analysis)

English An in vitro study

English Systematic review

English An in vivo study

English An in vitro study

English An in vitro study

English A book

English Review of article

English Review of article

A large number of dental materials present cytotoxic effects when applied close or directly to the pulp, and the only material that seems to stimulate early pulp repair and dentin hard tissue barrier formation is calcium hydroxide.

MTA presented a higher success rate compared to calcium hydroxide, presenting a lower occurrence of infection and pulp necrosis. 


\section{Continued}

Orucoglu, $\mathrm{H}$, Cobankara, F (2008)

Sharma, S., Hackett, R., Webb, R., Macpherson, D., Wilson, A. (2008)

Victorino, F., Bramante, C., Zapata, R.O., Casaroto, A.R. Garcia, R.B., Moraes, I.G., et al. (2010)

Barbizam, J.V., Trope,

M., Teixeira, E.C.

Tanomaru-Filho, M. Teixeira, F.B. (2008)

Faria, G., Kuga, M., Ruy, A.,

Aranda-Garcia, A.,

Bonettifilho, I.,

Guerreiro-Tanomaru,

J., et al. (2013)

Balvedi, R.P.A.,

Versiani, M.A.,

Manna, F.F., Biffi,

J.C.G. (2010)

Kuga, M,

30

Tanomaru-Filho, M,

Faria, G. (2010)

Rödig, T., Vogel, S.,

Taşdemir, $\mathrm{T}$, et al. (2011)
English Case report

English $\quad$ Case series

English An in vivo study

English An in vitro study

English An in vitro study

English An in vitro study

English In vitro study

English In vivo study
Gu, L.S., et al. (2009)
English

When calcium hydroxide paste that included barium sulfate was applied as an intracanal dressing and extruded through the periapical lesion associated with pulpless teeth, it had no detrimental effect.

This case series illustrates the high toxicity of calcium hydroxide when displaced into vessels and soft tissues.

The experimental propolis pastes presented acceptable physical characteristics to be used as intracanal medicaments.

The use of calcium hydroxide as an intracanal dressing material affected the adhesion of Epiphany to the root canal walls, but even though the values were within the acceptable range found in the literature.

None of the existing techniques completely removed the calcium hydroxide dressing. No difference was observed between self adjusting File (SAF) and ProTaper in removing calcium hydroxide in the middle $(\mathrm{P}=0.11)$ and the apical $(p=0.23)$ thirds. The SAF system showed similar efficacy to rotary instrument for removal of calcium hydroxide from mandibular incisor root canals.

Neither syringe injection nor passive ultrasonic irrigation methods were efficient in removing the inter-appointment root canal medicaments. Remnants of medicament were found in all experimental groups regardless of the vehicle used.

The efficacy of 2 types of rotary instruments (ProTaper and K3) employed in association with sodium hypochlorite or EDTA in removing calcium hydroxide residues from root canals dentin walls. ProTaper instrument was better than K3 Endo instrument in the removal of calcium hydroide intracanal medication, regardless of irrigating solution used.

None of the irrigants ( $1 \%$ sodium hypochlorite, $10 \%$ citric acid and $20 \%$ EDTA) nor their respective combinations were able to completely remove the calcium hydroxide. Chelating agents such as citric acid and EDTA showed the best results. The combination of chelators and $\mathrm{NaOCl}$ did not result in significant improvement of calcium hydroxide removal.

None of the techniques (irrigation with $5 \mathrm{~mL}$ of $2.5 \% \mathrm{NaOCl}$, irrigation with 5 $\mathrm{mL}$ of $17 \%$ EDTA in addition to $\mathrm{NaOCl}$, irrigation with $5 \mathrm{~mL}$ of $2.5 \% \mathrm{NaOCl}$ agitated by an ultrasonic unit, irrigation with $5 \mathrm{~mL}$ of $2.5 \% \mathrm{NaOCl}$ and a Canal Brush) removed the calcium hydroxide dressing completely. Canal Brush and ultrasonic agitation of sodium hypochloride were significantly more effective than irrigant-only techniques.

Technological advances during the last decade have brought to fruition new agitation devices that rely on various mechanisms of irrigant transfer, soft tissue debridement, and, depending on treatment philosophy, removal of smear layers. Overall, they appear to have resulted in improved canal cleanliness when compared with conventional syringe needle irrigation. 
Submit or recommend next manuscript to SCIRP and we will provide best service for you:

Accepting pre-submission inquiries through Email, Facebook, LinkedIn, Twitter, etc. A wide selection of journals (inclusive of 9 subjects, more than 200 journals)

Providing 24-hour high-quality service

User-friendly online submission system

Fair and swift peer-review system

Efficient typesetting and proofreading procedure

Display of the result of downloads and visits, as well as the number of cited articles

Maximum dissemination of your research work

Submit your manuscript at: http://papersubmission.scirp.org/

Or contact ojst@scirp.org 